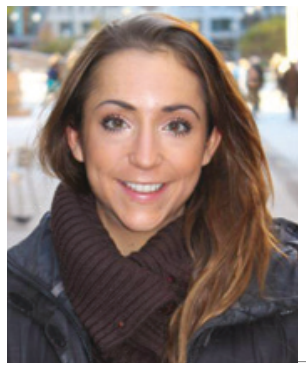

\title{
Å se hele mennesket
}

\author{
Min erfaring med helsevesenet er \\ at det kan preges av en manglende \\ helhetlig forståelse for individet. \\ Et kartesiansk skille mellom sjel \\ og legeme, kropp og sinn og psy- \\ kolog og lege kan hindre effektiv \\ behandling av pasientens sam- \\ mensatte helseplager.
}

Hvorfor har du anoreksi? For noen måneder siden befant jeg meg inne på kontoret til min nye fastlege for å diskutere resultatet av noen blodprøver. Etter flere års sykdom hadde jeg, ikke overraskende, avvikende verdier på en rekke av parameterne. Det var min første time med den nye fastlegen, så jeg forklarte ham at jeg hadde slitt med spiseforstyrrelser i flere år. «Hvorfor har du anoreksi?» spurte han meg. Forfjamset stotret jeg frem at det fors $\emptyset$ kte også jeg å finne ut av, og at jeg var under behandling hos en psykiater. Legen fulgte så opp med den klassiske kommentaren. Kommentaren jeg er blitt møtt med utallige ganger før. Kommentaren som jeg fortsatt sliter med ikke å gjenta for meg selv - daglig. Kommentaren som hindrer tusenvis av jenter å innrømme at de har et problem både for seg selv og for andre: «Kan du ikke bare begynne å spise da?»

Jeg kjente en bølge av skuffelse velte over meg. Har vi virkelig ikke kommet lenger? Etter årevis med søkelys på aksept og forståelse for spiseforstyrrelser, arbeid med å spre kunnskap om mental helse, har vi fortsatt leger som ikke ser kompleksiteten i det som ligger i bak. En pasients første møte med helsevesenet i slike sammenhenger kan være avgjørende for fremtidig helse og behandling, og da kan vi ikke akseptere en slik ignoranse blant noen av de viktigste tillitspersonene vi har. Dersom en lege bagatelliserer og dellegitimerer spiseforstyrrelser som sykdom, har vi et alvorlig problem. Anoreksi er en av de psykiske lidelsene som forårsaker flest dødsfall, og likevel opplever jeg og andre at den ikke alltid tas på alvor.

Etter flere år i behandling i helsevesenet har jeg også mange gode erfaringer og positive opplevelser. Jeg har møtt flere gode ressurspersoner som jeg har følt har sett hele meg. Dyktige spesialister og fagpersoner som er en del av et helsevesen som er i verdensklasse på en rekke områder. Men jeg har også dessverre altfor mange eksempler på det motsatte. Det er et ubestridelig faktum at menneskelige faktorer spiller inn i et behandlingsforløp. noe jeg også har full forståelse for. Likevel mener jeg at vi er tjent med å stille større krav til kunnskap og innsikt i psykisk helse for helsepersonell. Det er helt nødvendig at dagens leger får god nok kunnskap om det komplekse samspillet som er mellom kropp og sinn.

Denne kritikken kan jeg også rette mot meg selv og min bransje. Vi politikere er ofte for flinke til å prioritere politiske saker som gir umiddelbar effekt og synlighet, foran andre, og kanskje viktigere, men mindre synlige områder som forebygging. Å stå foran velgerne og klippe snoren til et nytt bygg er lettere enn å skryte over å ha fjernet muggsopp i kjelleren på et annet. $\AA$ A vise velgerne at man har bevilget penger til dobbelt så mange slankeoperasjoner, er lettere enn å snakke om forebyggingsarbeid for sunn ernæring i barneskolen. Vi bevilger enorme summer til helseforetakene hvert år samtidig som vi har opplevd en systematisk reduksjon av behandlingsplasser innenfor psykiatrien over flere år.

Jeg har selv vært vitne til fysisk og psykisk nedbrutte mennesker som desperat ber om hjelp og bistand til å komme seg på beina igjen. Når de da blir møtt med et svar om at ventelisten for behandling er ett år, er det for mange vanskelig å opprettholde motivasjonen. Ofte blir mennesker behandlet for de fysiske konsekvensene av en psykisk sykdom fremfor å bruke ressurser på å ta problemet med roten. Det burde bevilges mer ressurser til psykisk helsevern og behandling. Vi vet at mye sykdom har en psykosomatisk komponent, og at en styrking av psykisk helse også trolig vil lette presset i somatikken.

Samtidig må man prioritere lavterskeltilbud som helsesøsterordning, helsestasjon for ungdom og lettere tilgang til psykolog. Forståelsen for forebygging må være større enn søkelyset på nullsumstykket på budsjettet. Samarbeidet mellom psykisk og fysisk helsevern må styrkes betraktelig, både innenfor utdannings- og helsesektoren og blant bevilgende myndighet. Ideen bak samordningsreformen er god, men den er også et eksempel på hvordan kunstige skiller mellom ulike behandlingsformer er med på å skape utfordringer og tidvis et hinder av effektiv og god behandling av mennesker.

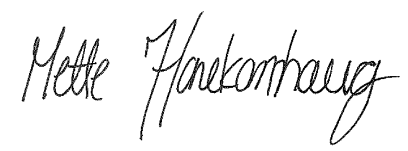

